\title{
The effect of a dietary herbal extract blend on the performance of broilers challenged with Eimeria oocysts
}

\author{
A. Arczewska-Włosek and S. Świątkiewicz ${ }^{1}$ \\ National Research Institute of Animal Production, \\ Department of Animal Nutrition and Feed Science \\ 32-083 Balice, Poland
}

(Received 28 September 2011; revised version 15 November 2011; accepted 12 March 2012)

\begin{abstract}
The aim of the experiment was to evaluate the anticoccidial efficacy of supplementing feeds with herbal extract blend containing garlic (Allium sativum), sage (Salvia officinalis), echinacea (Echinacea purpurea), thyme (Thymus vulgaris) and oregano (Origanum vulgare) extracts in broiler chickens experimentally infected with 170.000 sporulated oocysts of Eimeria acervulina, E. tenella, E. maxima and E. necatrix at 12 days of age. A total of 280 Ross 308 broilers were randomly allocated into 5 groups with 7 replicates of 8 chickens per replicate. The experimental dietary treatments were formulated by supplementing the basal maize-soyabean meal diet. The experimental design allocated the groups as follows: 1. uninfected birds and an unsupplemented diet; 2. uninfected birds and the diet supplemented with the herbal extract blend at a level of $1 \mathrm{~g} / \mathrm{kg}$ feed (200 $\mathrm{mg}$ of each herbal extract $/ \mathrm{kg}) ; 3$. infected birds and an unsupplemented diet; 4. infected birds and a diet with the addition of coccidiostat diclazuril at a level of $1 \mathrm{mg} / \mathrm{kg}$ feed; and 5. infected birds and a diet supplemented with the herbal extract blend at a level of $1 \mathrm{~g} / \mathrm{kg}$ feed ( $200 \mathrm{mg}$ of each herbal extract $/ \mathrm{kg}$ ). Throughout the 42 days of the experimental period, performance parameters, mortality, lesion score, oocyst output, and serum carotenoid concentration were recorded. Dietary supplementation with the herbal extract blend increased growth performance to the level found in the group fed the coccidiostat and in the non-challenged groups. The number of oocysts per gram of excreta did not differ significantly between the groups fed the herbal extract blend and the group receiving the coccidiostatic supplement. The herbal extract blend had no effect on mortality, lesion score, with the exception of the duodenum, or blood carotenoid concentration.
\end{abstract}

KEY WORDS: broiler chickens, coccidiosis, herbal extracts, performance, diclazuril, Eimeria

\footnotetext{
${ }^{1}$ Corresponding author: e-mail: sylwester.swiatkiewicz@izoo.krakow.pl
} 


\section{INTRODUCTION}

Coccidiosis, which is caused by protozoa of the genus Eimeria, is an intestinal parasitosis common in poultry. Infection results from ingestion of sporulated oocysts, which are universal contaminants of poultry environments. Global annual losses to the industry as a result of coccidiosis are estimated at over $\$ 3$ billion (Dalloul and Lillehoj, 2006). According to Williams (1999), coccidiosisrelated losses in the United Kingdom, estimated at thirty million pounds sterling, consisted of $80.6 \%$ lower production rates, i.e. higher mortality, reduced weight gain and higher feed conversion ratio, and $17.5 \%$ prevention and treatment costs.

In modern, intensive poultry production, the control of coccidiosis is based on chemoprophylaxis, which relies on the routine supplementation of feed with coccidiostats, taking into account the grace period and, on a lesser scale, immunoprophylaxis (vaccination). The improper use of coccidiostats has, however, led to the emergence of drug-resistant strains of Eimeria spp. (Ruff and Danforth, 1996). Moreover, there is strong evidence that residues of some coccidiostats may be present in the meat and the consumer is not being given adequate protection against this (Olejnik et al., 2009). The increasing drug resistance of coccidia, the risk of accumulation of these chemotherapeutic residues in meat and their potential negative impact on human health, consumer pressure in respect to food safety, and the risk of potential cross-resistance of microorganisms to the antimicrobials used to treat humans or animals gave rise to Regulation (EC) No 1831/2003 of the European Parliament and Council which provides for a ban on the prophylactic use of coccidiostats that will go into effect in 2013 (Anonymous, 2003). Consequently, there is great interest in the development of alternative methods for the prevention of coccidiosis. In this context, a number of plants and herbal products have been tested for their anticoccidial properties (Youn and Noh, 2001; Chandrakesan et al., 2009; Abbas et al., 2010; Lee et al., 2010; Haq et al., 2011).

On $1^{\text {st }}$ January 2008, The European Commission submitted a report (Anonymous, 2008) on the withdrawal of coccidiostats and histomonostats from use in feed additives. According to the EC, there is currently no comparably effective alternative to coccidiostats, although the search for their natural replacements is the subject of many studies. There is thus an urgent need to continue the studies in order to develop efficient coccidiostat substitutes. An optional method, or one complementary to vaccination, is the use of herbal plants that exhibit antimicrobial, antioxidant and anti-stress properties, exert effects on gut microflora, and show nutrigenomic effects and immune enhancement properties (Hashemi and Davoodi, 2010).

The aim of this study was to determine the effect of a dry herbal extract blend derived from garlic (Allium sativum), sage (Salvia officinalis), echinacea 
(Echinacea purpurea), thyme (Thymus vulgaris) and oregano (Origanum vulgare) on the course of coccidiosis in the gastrointestinal tract of broiler chickens.

\section{MATERIAL AND METHODS}

All of the experimental procedures involving animals were approved by the Local Animal Care and Use Committee.

In total, 280 one-day-old Ross 308 chicks of both sexes were randomly assigned to 5 experimental treatments. Each treatment was divided into 7 replicates (cages) of 8 birds ( 4 male and 4 female chicks). The chickens were reared to 42 days of age in wire-floored cages with free access to water and feed. All birds were fed with a starter (1 to $21 \mathrm{~d}$ ) and grower-finisher (22 to $42 \mathrm{~d}$ ) maize-soyabean meal basal diet, free of antibiotic growth promoters and coccidiostats and formulated to satisfy the nutrient requirements of broilers (Smulikowska and Rutkowski, 2005). Basal diets contained, \%: crude protein 22, Lys 1.23, Met 0.56, Ca 0.95 and available P 0.44, ME $/ \mathrm{kg} 12.4 \mathrm{MJ}$ (starter), or, crude protein 20, Lys 1.18, Met $0.51, \mathrm{Ca} 0.93$ and available P 0.41, ME/kg 13.1 MJ (grower-finisher). The experimental dietary treatments were formulated by supplementing the basal diet. The experimental design allocated the groups as follows: 1. uninfected birds and an unsupplemented diet; 2 . uninfected birds and the diet supplemented with the herbal extract blend derived from Allium sativum, Salvia officinalis, Echinacea purpurea, Thymus vulgaris and Origanum vulgare at a level of $1 \mathrm{~g} / \mathrm{kg}$ feed (200 mg of each herbal extract $/ \mathrm{kg}$ ); 3. infected birds and an unsupplemented diet; 4. infected birds and a diet with the addition of a coccidiostat, diclazuril, at a level of $1 \mathrm{mg} / \mathrm{kg}$ feed; and 5 . infected birds and a diet supplemented with the herbal extract blend at a level of $1 \mathrm{~g} / \mathrm{kg}$ feed $(200 \mathrm{mg}$ of each herbal extract $/ \mathrm{kg})$. From 1 to $11 \mathrm{~d}$ of age, all of the chickens were fed experimental diets, at $12 \mathrm{~d}$ of age groups 1 and 2 were orally inoculated with water, while birds from groups 3-5 were inoculated per os with 170,000 sporulated oocysts of E. acervulina, E. tenella, E. maxima and E. necatrix.

The birds were weighed at 1, 21 and $42 \mathrm{~d}$ of age. Body weight gain (BWG), feed intake (FI), feed conversion ratio (FCR) and mortality were calculated for $1-21,22-42$ and 1-42 d of age. The European broiler index (EBI) was calculated for the entire feeding period according to the equation (Koreleski et al., 2010):

$$
\begin{gathered}
\mathrm{EBI}=[\text { body weight }(\mathrm{kg}) \times \text { survival rate }(\%) / \text { age }(\text { days }) \times \mathrm{FCR}(\mathrm{kg} \text { feed } / \mathrm{kg} \\
\mathrm{BWG})] \times 100
\end{gathered}
$$

The number of oocysts per gram of excreta (OPG) was determined using a McMaster chamber (Mazurkiewicz, 2005) in pooled excreta samples taken from 
each replicate on post-inoculation days $6,7,8,9,14$ and 21 . Lesion scoring was performed on day 6 post-inoculation, and graded from 0 to 4 on the scale described by Conway and McKenzie (2007). Blood samples were collected from 6 birds in each group (one bird from replicates 1-6) on post-inoculation day 6 in order to analyse the carotenoid concentrations in serum filtrates (Negro et al., 1998).

At the end of the experiment and after $12 \mathrm{~h}$ feed withdrawal all chickens were weighed and 4 representative cockerels and 4 hens were chosen from each group (one male and one female from replicates 1-4) with live body weights close to the group average, marked with number signs and decapitated. Chickens were plucked, the intestines and crop were removed and carcasses stored overnight in $4^{\circ} \mathrm{C}$. The mass of the cooled carcass with edible giblets (gizzard, liver, heart) was estimated and carcass yield calculated. The breast muscles, abdominal fat, livers and gizzards were excised and weighed. The breast muscle and abdominal fat contents were expressed as \% of cold carcass. The weight of the liver and gizzard were expressed as \% of liveweight (Ziołecki and Doruchowski, 1989).

The data were analysed by means of one-way ANOVA and the significance of differences between mean values was assessed using Duncan's test (STATISTICA 5.0 software package; StatSoft, 1997). Differences were considered significant at $\mathrm{P}<0.05$.

\section{RESULTS}

The performance data obtained from the trial are given in Table 1. The production results in the first period of feeding confirmed the high efficiency of the experimental infection of the chickens with viable oocysts. The mixed Eimeria infection negatively affected BWG, FCR and mortality at $21 \mathrm{~d}$ of age, which is post-inoculation day 9 (groups 3-5 vs 1 and 2). The BWG of the infected chickens fed the unsupplemented diet were more than $40 \%$ lower compared with the group of uninfected ones (Table 1). The addition of the herbal extract blend to the diet (group 5) alleviated the negative effects of the infection, thus BWG and FCR were superior by 25.0 and $19.5 \%$ over the infected and unsupplemented group (group $5)$. The highest mortality rate was noted in group 5 , however.

In the second feeding phase (22-42 day of age), the trend towards deterioration in BWG and FCR in the infected group of chickens fed the unsupplemented diet was statistically confirmed $(\mathrm{P}<0.05)$. The performance indices in the group of infected chickens (group 5) receiving the herbal extract blend did not statistically differ from those chickens (group 4) fed the diet supplemented with the coccidiostat (Table 1). 
Table 1. Effect of experimental treatments on performance of broiler chickens

\begin{tabular}{|c|c|c|c|c|c|c|c|}
\hline $\begin{array}{l}\text { Group } \\
\text { number }\end{array}$ & $\begin{array}{c}\text { Infection } \\
\text { with Eimeria } \\
\text { oocysts }\end{array}$ & $\begin{array}{l}\text { Dietary } \\
\text { treatment }\end{array}$ & $\begin{array}{c}\text { Body weight } \\
\text { gain (BWG) } \\
\text { g }\end{array}$ & $\begin{array}{c}\text { Feed } \\
\text { intake } \\
\mathrm{g}\end{array}$ & $\begin{array}{c}\text { Feed } \\
\text { conversion } \\
\text { ratio } \\
\text { g feed } / \mathrm{g} \text { BWG }\end{array}$ & $\begin{array}{c}\text { Mortality } \\
\%\end{array}$ & $\begin{array}{l}\text { European } \\
\text { broiler index } \\
\text { points }\end{array}$ \\
\hline \multicolumn{8}{|c|}{ Days 1-21 } \\
\hline 1 & - & - & $518^{\mathrm{a}}$ & $896^{\mathrm{a}}$ & $1.73^{\mathrm{a}}$ & 0 & \\
\hline 2 & - & Herbal extracts & $501^{\mathrm{a}}$ & $858^{\mathrm{ab}}$ & $1.71^{\mathrm{a}}$ & 0 & \\
\hline 3 & + & - & $307^{\mathrm{c}}$ & $790^{\mathrm{b}}$ & $2.66^{\mathrm{c}}$ & 19.6 & \\
\hline 4 & + & Diclazuril & $418^{\mathrm{b}}$ & $889^{\mathrm{a}}$ & $2.14^{\mathrm{b}}$ & 19.6 & \\
\hline 5 & + & Herbal extracts & $384^{\mathrm{b}}$ & $839^{\mathrm{ab}}$ & $2.19^{b}$ & 25.0 & \\
\hline SEM & & & 14.6 & 14.1 & 0.078 & & \\
\hline \multicolumn{8}{|c|}{ Days 22-42 } \\
\hline 1 & - & - & $1663^{\mathrm{ab}}$ & 3199 & 1.93 & 0.0 & \\
\hline 2 & - & Herbal extracts & $1686^{\mathrm{a}}$ & 3176 & 1.88 & 0.0 & \\
\hline 3 & + & - & $1585^{\mathrm{b}}$ & 3076 & 1.94 & 1.8 & \\
\hline 4 & + & Diclazuril & $1723^{\mathrm{a}}$ & 3339 & 1.94 & 1.8 & \\
\hline 5 & + & Herbal extracts & $1701^{\mathrm{a}}$ & 3164 & 1.86 & 0.0 & \\
\hline SEM & & & 15.9 & 40.7 & 0.023 & & \\
\hline \multicolumn{8}{|c|}{ Days $1-42$} \\
\hline 1 & - & - & $2181^{\mathrm{a}}$ & $4095^{\mathrm{ab}}$ & $1.88^{\mathrm{a}}$ & 0.0 & $282^{\mathrm{a}}$ \\
\hline 2 & - & Herbal extracts & $2186^{\mathrm{a}}$ & $4030^{\mathrm{ab}}$ & $1.84^{\mathrm{a}}$ & 0.0 & $288^{\mathrm{a}}$ \\
\hline 3 & + & - & $1892^{\mathrm{b}}$ & $3904^{\mathrm{b}}$ & $2.06^{\mathrm{b}}$ & 21.4 & $177^{\mathrm{b}}$ \\
\hline 4 & + & Diclazuril & $2141^{\mathrm{a}}$ & $4238^{\mathrm{a}}$ & $1.99^{\mathrm{ab}}$ & 21.4 & $212^{\mathrm{b}}$ \\
\hline 5 & + & Herbal extracts & $2085^{\mathrm{a}}$ & $4026^{\mathrm{ab}}$ & $1.93^{\mathrm{ab}}$ & 25.0 & $197^{\mathrm{b}}$ \\
\hline SEM & & & 24.8 & 75.7 & 0.04 & & 18.4 \\
\hline
\end{tabular}

Analysis of the results for the entire experimental period showed a statistically significant decrease in BWG, EBI and poor FCR in the infected chickens that received no additive in the feed, in comparison with the non-infected groups. The growth performance indices obtained in the infected chickens fed the diet supplemented with the herbal extract blend were comparable to those recorded in the group given the coccidiostat-supplemented diet and both uninfected groups. The exception was the EBI value, which did not differ among any of the infected groups and was influenced by the high mortality rate, which reached $21.4 \%$ in groups 3 and 4 and $25 \%$ in group 5 (Table 1 ).

The results of the slaughter analysis showed no differences between the experimental groups in respect to the analysed parameters, with the exception of the abdominal fat content in the carcass, which was the lowest in the infected group fed the diet supplemented with the herbal extract blend (Table 2). 
Table 2. Effect of experimental treatments on results of slaughter analysis $(n=8)$

\begin{tabular}{cccccccc}
\hline $\begin{array}{l}\text { Group } \\
\text { number }\end{array}$ & $\begin{array}{c}\text { Infection } \\
\text { with Eimeria } \\
\text { oocysts }\end{array}$ & $\begin{array}{c}\text { Dietary } \\
\text { treatment }\end{array}$ & $\begin{array}{c}\text { Carcass } \\
\text { yield } \\
\text { \% LBW }\end{array}$ & $\begin{array}{c}\text { Breast meat } \\
\text { yield } \\
\text { \% carcass }\end{array}$ & $\begin{array}{c}\text { Abdominal } \\
\text { fat, \% carcass }\end{array}$ & $\begin{array}{c}\text { Liver } \\
\% \text { LBW }\end{array}$ & $\begin{array}{c}\text { Gizzard } \\
\% \text { LBW }\end{array}$ \\
\hline 1 & - & - & 76.5 & 23.3 & $2.27^{\mathrm{b}}$ & 1.83 & 1.26 \\
2 & - & Herbal extracts & 76.6 & 23.1 & $1.83^{\mathrm{ab}}$ & 1.91 & 1.29 \\
3 & + & - & 76.6 & 23.4 & $1.81^{\mathrm{ab}}$ & 1.98 & 1.20 \\
4 & + & Diclazuril & 76.9 & 23.4 & $1.87^{\mathrm{ab}}$ & 1.81 & 1.19 \\
5 & + & Herbal extracts & 76.2 & 23.4 & $1.51^{\mathrm{a}}$ & 1.86 & 1.21 \\
SEM & & & 0.136 & 0.243 & 0.088 & 0.03 & 0.017 \\
\hline
\end{tabular}

a, b - means in columns with different superscripts differ significantly at $\mathrm{P}<0.05$

${ }^{1} \mathrm{LBW}$ - live body weight before slaughter

The concentration of OPG confirms the high effectiveness of the experimental infection of the chickens with sporulated Eimeria oocysts (Table 3). The highest OPG value was recorded in the excreta collected from group 3 on post-inoculation

Table 3. Effect of experimental treatments on oocyst counts, thous./1 g of excreta

\begin{tabular}{|c|c|c|c|c|c|c|c|c|}
\hline \multirow{2}{*}{$\begin{array}{l}\text { Group } \\
\text { number }\end{array}$} & \multirow{2}{*}{$\begin{array}{c}\text { Infection } \\
\text { with Eimeria } \\
\text { oocysts }\end{array}$} & \multirow{2}{*}{$\begin{array}{l}\text { Dietary } \\
\text { treatment }\end{array}$} & \multicolumn{6}{|c|}{ Days post infection } \\
\hline & & & 6 & 7 & 8 & 9 & 14 & 21 \\
\hline 1 & - & - & $0^{\mathrm{a}}$ & $0^{\mathrm{a}}$ & $0^{\mathrm{a}}$ & $0^{\mathrm{a}}$ & $0^{\mathrm{a}}$ & $0^{\mathrm{a}}$ \\
\hline 2 & - & Herbal extracts & $0^{\mathrm{a}}$ & $0^{\mathrm{a}}$ & $0^{\mathrm{a}}$ & $0^{\mathrm{a}}$ & $0^{\mathrm{a}}$ & $0^{\mathrm{a}}$ \\
\hline 3 & + & - & $2788^{c}$ & $950^{\mathrm{b}}$ & $419^{c}$ & $99.8^{c}$ & $64.5^{\mathrm{c}}$ & $1.12^{\mathrm{ab}}$ \\
\hline 4 & + & Diclazuril & $1931^{\mathrm{b}}$ & $814^{b}$ & $103^{\mathrm{ab}}$ & $10.5^{\mathrm{a}}$ & $34.5^{\mathrm{b}}$ & $0.90^{\mathrm{ab}}$ \\
\hline 5 & + & Herbal extracts & $1587^{\mathrm{b}}$ & $700^{\mathrm{b}}$ & $179^{\mathrm{b}}$ & $71.1^{\mathrm{b}}$ & $27.0^{\mathrm{b}}$ & $1.74^{\mathrm{b}}$ \\
\hline SEM & & & 249 & 91.6 & 35.2 & 8.69 & 5.68 & 0.241 \\
\hline
\end{tabular}

a,b,c - means in columns with different superscripts differ significantly at $\mathrm{P}<0.05$

day 6 and was statistically higher in comparison with those obtained from the remaining infected groups. A similar profile of differences in OPG value was also recorded on post-inoculation days 8,9 and 14 . The addition of the herbal extract blend significantly lowered the OPG value to the level recorded for the group given the coccidiostat. Oocysts were not found in the excreta samples from the uninfected birds. Moreover, the uninfected birds were free of lesions; cross contamination had thus not occurred (Table 4). In all of the infected groups, macroscopic lesions were highest in the caeca, which is the site of invasion for the strongly pathogenic $E$. tenella. There were no differences in lesions among the infected groups, with the exception of the lesions observed in the duodenum of the birds, which were most severe in group 3, i.e. in birds that were infected and fed the unsupplemented diet.

The statistically significant reduction in serum carotenoid concentration was found in all of the groups of infected chickens, as compared with the uninfected groups. Nonetheless, supplementing the diet with the coccidiostat or herb extract 
blend had no statistically confirmed effect on the serum carotenoid concentration in the infected birds (Table 4).

Table 4. Effect of experimental treatments on lesion score (0-4) and serum carotenoids concentration at $6 \mathrm{~d}$ post-inoculation $(\mathrm{n}=6)$

\begin{tabular}{ccccccc}
\hline $\begin{array}{l}\text { Group } \\
\text { number }\end{array}$ & $\begin{array}{c}\text { Infection with } \\
\text { Eimeria } \text { oocysts }\end{array}$ & $\begin{array}{c}\text { Dietary } \\
\text { treatment }\end{array}$ & $\begin{array}{c}\text { Duodenum } \\
\text { points }\end{array}$ & $\begin{array}{c}\text { Jejunum, } \\
\text { ileum, points }\end{array}$ & $\begin{array}{c}\text { Caeca } \\
\text { points }\end{array}$ & $\begin{array}{c}\text { Carotenoids } \\
\mathrm{mg} / 1\end{array}$ \\
\hline 1 & - & - & $0.0^{\mathrm{a}}$ & $0.0^{\mathrm{a}}$ & $0.0^{\mathrm{a}}$ & $1.419^{\mathrm{a}}$ \\
2 & - & Herbal extracts & $0.0^{\mathrm{a}}$ & $0.0^{\mathrm{a}}$ & $0.0^{\mathrm{a}}$ & $1.406^{\mathrm{a}}$ \\
3 & + & - & $2.33^{\mathrm{c}}$ & $1.58^{\mathrm{b}}$ & $3.08^{\mathrm{b}}$ & $0.327^{\mathrm{b}}$ \\
4 & + & Diclazuril & $1.83^{\mathrm{b}}$ & $1.67^{\mathrm{b}}$ & $2.92^{\mathrm{b}}$ & $0.370^{\mathrm{b}}$ \\
5 & + & Herbal extracts & $1.92^{\mathrm{b}}$ & $1.33^{\mathrm{b}}$ & $3.25^{\mathrm{b}}$ & $0.420^{\mathrm{b}}$ \\
SEM & & & 0.195 & 0.181 & 0.302 & 0.109 \\
\hline
\end{tabular}

a,b,c, - means in columns with different superscripts differ significantly at $\mathrm{P}<0.05$

\section{DISCUSSION}

The data presented in this paper confirms the detrimental effect of coccidiosis on performance parameters, mortality, lesion scoring, and blood carotenoid concentration. The high mortality recorded in all of the infected groups, primarily during the first days after inoculation, indicates the high pathogenicity of the field strain inoculant used in the experiment.

The worst growth performance data were found in the group of infected chickens fed the unsupplemented diet. The significantly lower BWG in this group during all feeding periods was a consequence of reduced feed intake and the disruption of intestinal integrity, which affected the absorption of nutrients and the efficiency of feed utilization, these being common effects of coccidiosis (Peek and Landman, 2003; Walk et al., 2011). The detrimental effect of infection was also reflected in the highest OPG recorded in the excreta collected on post-infection days $6,8,9$ and 14 and in the lesion score of the duodenum on post-infection day 6. The duodenum is the site of invasion for E. acervulina, which does not cause a drastic increase in mortality, but has a negative impact on the digestion, absorption and assimilation of nutrients (Adams et al., 1996).

The tested herbal extract blend was shown to alleviate the deleterious effect of the experimental infection and was as efficient in the improvement of BWG, FI, FCR, and lowering of OPG as the coccidiostat used; however, it did not exert a beneficial effect on the mortality rate in first period of feeding. The efficacy of the herbs tested in the present trial has previously been evaluated in other experiments; however, these herbs have never been used together as an herbal extract blend. Giannenas et al. (2003) demonstrated a significant improvement of performance, survival rate, lesion score and oocyst numbers in chickens infected with $E$. tenella 
and fed diets supplemented with oregano essential oil (300 mg/kg), in comparison with an infected group fed an unsupplemented diet, but the improvements were lower than in chickens fed a diet with the coccidiostat, lasalocid. Oregano extract used to supplement vaccination for the prevention of coccidiosis in organically reared chickens has also been shown to have a positive effect on weight gain in uninfected birds (Waldenstedt, 2003). Feed supplementation with 0.1 or $0.5 \%$ immunopotential Echinacea purpurea during the first 2 weeks of life has been demonstrated to significantly improve BWG and reduce total lesion scores in vaccinated broilers, as compared with those given a live vaccination alone (Allen, 2003). Similarly, the anticoccidial effect exerted by sage, thyme and their phenols, such as cineol, borneol, thymol and carvacrol has been established (Ibrir et al., 2001; Szaboova et al., 2008).

In the current study data from uninfected birds receiving the herbal extract blend suggest that these additives have no effect on growth parameters and carotenoid concentration. It can thus be assumed that the beneficial effect of the extracts obtained in the group of infected chickens was not a consequence of its stimulating influence on the birds' appetite, but a result of its anticoccidial properties. The lower OPG recorded in the infected group given the herbal extract was comparable with that obtained in the group being administered the coccidiostat and was probably the effect of the phenolic compounds in the herbal extracts. Phenols can interact with cytoplasmic membranes and change their cation permeability, leading to impairment of crucial processes in the coccidia cells and, finally, their death (Sikkema et al., 1995).

In the face of the ban on the prophylactic use of coccidiostats in the EU that will go into effect in 2013, the search among substances of natural origin for alternative methods of controlling coccidiosis seems to be highly justified. In addition to the advantages previously mentioned, herbal extracts do not carry the risk of contaminating meat with harmful substances. To date, the emergence of resistance to herbal products among coccidia species has not been reported.

\section{CONCLUSIONS}

In conclusion, the results of the present study suggest that treatment with a herbal extract blend comprising Allium sativum, Salvia officinalis, Echinacea purpurea, Thymus vulgaris and Origanum vulgare at a dose of $1 \mathrm{~g} / \mathrm{kg}$ partly alleviates the negative impact of Eimeria infection in broiler chickens. The beneficial effect of the herbal extract blend on the growth performance and number of oocytes per gram of excreta of the infected chickens was comparable to that exhibited by diclazuril. 


\section{REFERENCES}

Abbas R.Z., Iqbal Z., Khan M.N., Zafar M.A., Zia M.A., 2010. Anticoccidial activity of Curcuma longa L. in broilers. Braz. Arch. Biol. Technol. 52, 63-67

Adams C., Vahl H. A., Veldman A., 1996. Interaction between nutrition and Eimeria acervulina infection in broiler chickens: diet compositions that improve fat digestion during Eimeria acervulina infection. Brit. J. Nutr. 75, 875-880

Allen P.C., 2003. Dietary supplementation with Echinacea and development of immunity to challenge infection with coccidia. Parasitol. Res. 91, 74-78

Anonymus, 2003. Regulation (EC) No 1831/2003 of the European Parliament and of the Council of 22 September 2003 on additives for use in animal nutrition. Off. J. Europ. Union, L 268, $29-43$

Anonymus, 2008. Report from the Commission to the Council and the European Parliament on the use of coccidiostats and histomonostats as feed additives. Brussels, 5.5.2008, COM(2008)233

Chandrakesan P., Muralidharan K., Kumar V.D., Ponnudurai G., Harikrishnan T.J., Rani K.S.V.N., 2009. Efficacy of a herbal complex against caecal coccidiosis in broiler chickens. Vet. Arh. 79, 199-203

Conway D. P., McKenzie, M.E., 2007. Poultry Coccidiosis: Diagnostic and Testing Procedures. $3^{\text {rd }}$ Edition. Blackwell Publ. Ames, Iowa (USA)

Dalloul R.A., Lillehoj H.S., 2006. Poultry coccidiosis: recent advancements in control measures and vaccine development. Expert Rev. Vacc. 5, 143-163

Giannenas A.I., Florou-Paneri P., Papazahariadou M., Christaki E., Botsoglou N.A., Spais A.B., 2003. Effect of dietary oregano essential oil supplementation on performance of broilers challenged with Eimeria tenella. Arch. Anim. Nutr. 57, 99-106

Haq I., Pasha T., Khalique A., 2011. Comparative efficacy of herbal and allopathy drugs against coccidiosis in poultry. Ital. J. Anim. Sci. 10, 14-16

Hashemi S.R., Davoodi H., 2010. Phytogenics as new class of feed additive in poultry industry. J. Anim. Vet. Adv. 9, 2955-2304

Ibrir F., Greathead H.M.R., Forbes J.M., 2001. The effect of thymol/carvacrol treatments on the performance of broiler chickens infected with Eimeria acervulina. In: Proceedings of AFAC Workshop 'Alternatives to Feed Antibiotics and Anticoccidials in the Pig and Poultry Meat Production', pp. 1-2 (http://www2.slu.se/Workshop20Norge/Poster \%20abstract2F\%20brir.pdf)

Koreleski J., Świątkiewicz S., Arczewska A., 2010. The effect of dietary potassium and sodium on performance, carcass traits, and nitrogen balance and excreta moisture in broiler chickens. J. Anim. Feed Sci. 19, 244-256

Lee S.H., Lillehoj H.S., Jang S.I., Kim D.K., Ionescu C., Bravo D., 2010. Effect of dietary Curcuma, Capsicum, and Lentinus on enhancing local immunity against Eimeria acervulina infection. J. Poultry Sci. 47, 87-85

Mazurkiewicz M., 2005. Poultry Diseases (in Polish). Wroclaw University of Environmental and Life Sciences (Editor). Wrocław (Poland)

Negro J.J., Bortolotti G.R., Tella J.L., Fernie K.J., Bird D.M., 1998. Regulation of integumentary colour and plasma carotenoids in American Kestrels consistent with sexual theory. Funct. Ecol. $12,307-312$

Olejnik M., Szprengier-Juszkiewicz T., Żmudzki J., 2009. Coccidiostats residues in poultry tissues and eggs. Med. wet. 65, 807-811

Peek H.W., Landman W.J.M., 2003. Resistance to anticoccidial drugs of Dutch avian Eimeria spp. field isolates originating from 1996, 1999 and 2001. Avian Pathol. 32, 391-401 
Ruff M.D., Danforth H.D., 1996. Resistance of coccidia to medications. In: Proceedings of XX World's Poultry Congress. New Delhi. Vol. II, pp. 427-430

Sikkema J., De Bont J.A.M., Poolman B., 1995. Mechanisms of membrane toxicity of hydrocarbons. Microbiol. Rev. 59, 201-222

Smulikowska S., Rutkowski A. (Editors), 2005. Recommended Allowances and Nutrition Value of Feedstuffs. Poultry Feeding Standards (in Polish). $4^{\text {th }}$ Edition. The Kielanowski Institute of Animal Physiology and Nutrition, PAS, Jabłonna (Poland) and Polish Branch of WPSA

StatSoft, 1997. Statistica for Windows Version 5.0. StatSoft Inc. Tulsa, OK

Szaboova R., Laukova A., Chrastinova L., Simonova M., Strompfova V., Haviarova M., Placha I., Faix S., Vasilkova Z., Chrenkova M., Rafay J., 2008. Experimental application of sage in rabbit husbandry. Acta Vet. Brno 77, 581-588

Waldenstedt L., 2003. Effect of vaccination against coccidiosis in combination with an antibacterial oregano (Origanum vulgare) compound in organic broiler production. Acta Agr. Scand., Sect. A. Anim. Sci. 53, 101-109

Walk C.L., Cowieson A.J., Remus J.C., Novak C.L., McElroy A.P., 2011. Effects of dietary enzymes on performance and intestinal goblet cell number of broilers exposed to a live coccidia oocyst vaccine. Poultry Sci. 90, 91-98

Williams R.B., 1999. A compartmentalized model for the estimation of the cost of coccidiosis to the world's chicken production industry. Int. J. Parasitol. 29, 1209-1229

Youn H.J., Noh J.W., 2001. Screening of the anticoccidial effects of herbs extracts against Eimeria tenella. Vet. Parasitol. 96, 257-263

Ziołecki J., Doruchowski W., 1989. The Method for Evaluation of Poultry Carcass (in Polish). COBRD Publishing. Poznań (Poland) 